\title{
VIABILIDADE DE CANDIDA ALBICANS APÓS TRATAMENTO COM GÉIS CLAREDORES DENTAIS
}

Laura CAVALCA; Luciane Grochocki RESENDE; Rosimeire ROSA; Edvaldo ROSA; Rodrigo Nunes RACHED.

Embora os agentes de clareamento dental venham sendo utilizados extensivamente, efeitos biológicos adversos sobre estruturas do organismo e bactérias têm sido reportados, não sendo relatado os seus efeitos sobre os fungos. O objetivo deste estudo foi avaliar a toxicidade in vitro de um agente clareador caseiro (peróxido de carbamida 16\% (PC), Whiteness ${ }^{\circledR}$ Perfect, FGM) e um clareador de consultório (peróxido de hidrogênio 35\% $(\mathrm{PH}$ ) Whiteness ${ }^{\circledR}$ HP Maxx, FGM) e seus excipientes sobre Candida albicans crescida em fase planctônica após exposição continuada. Os produtos PC e PH apresentaram efeito fungicida para as células em fase planctônica nos tempos investigados. Os produtos excipientes de PC e $\mathrm{PH}$ apresentaram ação fúngica.Os resultados indicaram que tanto o agente clareador quanto os seus excipientes apresentaram toxidade para Candida albicans em fase planctônica nos tempos investigados. 